\title{
Inhibition of Fibroblast Apoptosis by Borrelia afzelii, Coxiella burnetii and Bartonella henselae
}

\author{
TOMASZ CHMIELEWSKI* and STANISŁAWA TYLEWSKA-WIERZBANOWSKA
}

\author{
Laboratory of Rickettsiae, Chlamydiae and Spirochetes, National Institute of Public Health \\ - Natonal Institute of Hygiene, Warsaw, Poland
}

Received 2 June 2011, accepted 10 July 2011

Abstract

Apoptosis is a genetically controlled mechanism of cell death involved in the regulation of tissue homeostasis. The aim of this study was to investigate the influence of Borrelia afzelii, Coxiella burnetii, and Bartonella henselae bacteria on apoptosis measured as the level of caspase 3 activity in human fibroblast cells HEL-299. Our findings show that $C$. burnetii bacteria may inhibit the process of apoptosis in the host cells for a long time. This can permit intracellular survival in the host and mediatingthe development of chronic disease.

Key words: Borrelia afzelii, Coxiella burnetii, Bartonella henselae, fibroblasts, apoptosis

Apoptosis is a genetically controlled mechanism of cell death involved in the regulation of tissue homeostasis. It has been found that some viral, bacterial and parasitic pathogens affect the viability of the host cell, inhibiting or promoting apoptosis (Carmen et al., 2006; Clifton et al., 1998; Fischer et al., 2004; Radulovic et al., 2002). In this process, activation of mediators called caspases plays a key role in the destruction phase of cell apoptosis. At least 13 different caspases have been identified, which belong to three different subfamilies, depending on their substrate specificity.

Caspase 3 is a cytosolic protein found in cells as an inactive $32 \mathrm{kDa}$ proenzyme, and it is activated by various death signals into $20 \mathrm{kDa}(\mathrm{p} 20)$ and $11 \mathrm{kDa}(\mathrm{p} 11)$ active subunits. Both subunits contribute to substrate binding and catalysis. This protein cleaves and activates caspases 6, 7, and 9; moreover the protein itself is processed by caspases 8,9 , and 10 (Gołąb 2009).

The aim of our studies was to investigate the influence of Borrelia afzelii, Coxiella burnetii, and Bartonella henselae bacteria on apoptosis measured as the level of caspase 3 activity in human fibroblast cells.

A suspension of B. henselae bacterial cells (ATCC 49882) used for evaluations was obtained by growing on chocolate agar containing 5\% defibrinated sheep blood in a humid atmosphere with $5 \% \mathrm{CO}_{2}$ at $35^{\circ} \mathrm{C}$ and harvested after 5 days when bacterial growth was sufficient. A final inoculum of $10^{6} \mathrm{cfu} / \mathrm{spot}$ was used for inoculation in HEL-299 (Dörbecker et al., 2006).
Borrelia afzelii strain VS 461 (ATCC 51567) was grown at $35^{\circ} \mathrm{C}$ in BSK-H Medium Complete (Sigma-Aldrich, USA) to a cell density of $10^{7} / \mathrm{ml}$ (Pollack et al., 1993).

C. burnetii (strain Henzerling) was cultured in HEL-299 (ATCC-CCL-137) human fibroblast cells in shell-vials containing $5 \mathrm{ml}$ of Eagle's Minimum Essential Medium (EMEM) medium with Earle's BSS, $2 \mathrm{mM} \mathrm{L}$-glutamine and supplemented with $5 \%$ fetal bovine serum for 14 days. Cells were infected with the supernatant containing C. burnetii to a fresh monolayer and incubated in $5 \% \mathrm{CO}_{2}$ atmosphere at $35^{\circ} \mathrm{C}$ (Raoult et al., 1990).

HEL-299 - human fibroblasts cells (ATCC-CCL-137) were cultured in shell-vials (Bibby Sterilin, Staffordshire, United Kingdom) containing $2 \mathrm{ml}$ of EMEM with Earle's BSS, $1 \mathrm{mM}$ sodium pyruvate, $2 \mathrm{mM}$ L-glutamine (ATCC, Manassas, Canada) and supplemented with $5 \%$ fetal bovine serum. After two days the cells were infected with $100 \mu \mathrm{l}$ C. burnetii, B. henselae and B. afzelii cultures. As a control, uninfected HEL299 cells were tested. Both infected and uninfected cells were incubated in $5 \% \mathrm{CO}_{2}$ atmosphere at $35^{\circ} \mathrm{C}$.

The course of human fibroblast apoptosis was evaluated by determination of caspase- 3 activity at the same time in infected cell cultures after six hours post infection, on $7^{\text {th }}, 14^{\text {th }} 21^{\text {st }}$ and $28^{\text {th }}$ day of infection. All tests were run in triplicate.

The presence of enzyme activity in cells lysates was determined with a Human Caspase-3 Instant ELISA

* Corresponding author: T. Chmielewski, National Institute of Public Health - National Institute of Hygiene, ul. Chocimska 24, 00-791 Warszawa; phone: 022-5421261; e-mail: tchmielewski@pzh.gov.pl 
(Bender MedSystems, Austria) according to the manufacturer's protocol. Infected and uninfected cells adhering to cover slips in shell-vials were washed twice with PBS. Cells were incubated 60 minutes at room temperature with gentle shaking in lysing buffer (Lysis buffer, Bender MedSystems, Austria), then centrifuged at $1000 \mathrm{~g}$ for 15 minutes. Supernatants were stored at $-80^{\circ} \mathrm{C}$ and assayed at the same time. Absorbance of each sample was measured in duplicate on spectrophotometer at wavelength $450 \mathrm{~nm}$. Concentration was calculated from a standard curve, created by plotting the mean absorbance for each standard concentration.

Data were compared with the Mann-Whitney's statistical test, and p-value less than 0.05 (level of significance) was considered statistically significant. Calculations were performed using the statistical package $\mathrm{R}$ Development Core Team, 2011 (Vienna, Austria).

Caspase 3 activity in HEL299 cell line infected with B. afzelii, B.henselae and C.burnetii was compared. During 28 days a slight increase from 0.43 to $0.48 \mathrm{ng} / \mathrm{ml}$ was detected in uninfected cells.

In cells infected with $B$. afzelii strain, the initial level of caspase 3 activity was $0.43 \mathrm{ng} / \mathrm{ml}$. It showed a steady increase from $0.41 \mathrm{ng} / \mathrm{ml}, 0.44 \mathrm{ng} / \mathrm{ml}, 0.55 \mathrm{ng} / \mathrm{ml}$ to $0.56 \mathrm{ng} / \mathrm{ml}$ on $7^{\text {th }}, 14^{\text {th }}, 21^{\text {st }}$ and $28^{\text {th }}$ days after infection, respectively.

In cell cultures infected with $B$. henselae strain, a decrease of caspase- 3 activity was observed, from $0.45 \mathrm{ng} / \mathrm{ml}$ on the first day of infection to $0.34 \mathrm{ng} / \mathrm{ml}$ and $0.36 \mathrm{ng} / \mathrm{ml}$ after 7 and 14 days, followed by an increase to $0.48 \mathrm{ng} / \mathrm{ml}$ and $0.49 \mathrm{ng} / \mathrm{ml}$ after 21 and 28 days of incubation.

In cell culture inoculated with C. burnetii a decrease in the level of the enzyme activity from $0.45 \mathrm{ng} / \mathrm{ml}$ on the $1^{\text {st }}$ day to the level of $0.35 \mathrm{ng} / \mathrm{ml}$ on $7^{\text {th }}$ day and $0.31 \mathrm{ng} / \mathrm{ml}$ on $14^{\text {th }}$ day was observed. After 21 and
28 days the level stabilized at $0.34 \mathrm{ng} / \mathrm{ml}$ and $0.35 \mathrm{ng} /$ $\mathrm{ml}$ (Table I).

Comparing caspase 3 activity levels on the $1^{\text {st }}$ and $28^{\text {th }}$ day, a $17 \%$ increase in B. afzelii infected HEL299 cultures $(p=0.1)$ and $2 \%$ increase in cell cultures infected with $B$. henselae ( $p=0.4$ ) was observed, compared to uninfected HEL-299.

In cell culture infected with Coxiella burnetii a 27\% decrease in caspase 3 activity was detected $(p=0.1)$.

The p-values greater than 0.05 and equal or less than 0.10 may be treated as the border of statistical significance due to the small number of tests.

In the present studies, the process of apoptosis on the basis of caspase 3 activity in human fibroblasts in vitro was monitored. In C. burnetii infected HEL 299 caspase activity decreased after 7 days and was $22 \%$ less after 28 days than the initial level on the first day of infection. Inhibition was observed throughout the incubation period. At the same time, caspase 3 activity increased during four weeks of incubation in uninfected cell culture and in cells infected with B. azelii and B. henselae (Fig. 1).

Several reports have described interactions between B. burgdorferi bacteria and various host cells. It has been shown that the spirochetes can enter mammalian immune cells and other cells as well as tick tissue. This process allows the pathogen to survive in host tissues, to infect them and to escape the host defense ( $\mathrm{Hu}$ and Klempner, 1997; Klempner et al., 1993; Linder et al., 2001; Peters and Benach, 1997; Sigal 1997; Szczepanski et al., 1990; Thomas and Comstock 1989). Our study reveals that $B$. afzelii bacteria have the ability to inhibit apoptosis only for a short period of time compared to C. burnetii. Electron microscopic studies have revealed the consecutive steps of the B. burgdorferi life cycle in vitro. The spirochetes penetrate into fibroblasts.

Table I

Levels of caspase 3 activity (ng/ml) in cultures HEL 299 infected with Bartonella henselae, Borrelia afzelii, Coxiella burnetii

\begin{tabular}{|c|c|c|c|c|}
\hline \multirow{2}{*}{ Day } & \multicolumn{3}{|c|}{$\begin{array}{l}\text { Caspase } 3 \text { activity measured in } \mathrm{ng} / \mathrm{ml} \text { with standard } \\
\text { deviation in cultures HEL } 299 \text { infected with }\end{array}$} & \multirow{2}{*}{$\begin{array}{c}\text { Caspase } 3 \text { activity } \\
\text { measured in } \mathrm{ng} / \mathrm{ml} \\
\text { in uninfected } \\
\text { HEL } 299 \text { culture }\end{array}$} \\
\hline & $\begin{array}{l}\text { Bartonella } \\
\text { henselae }\end{array}$ & $\begin{array}{c}\text { Borrelia } \\
\text { afzelii }\end{array}$ & $\begin{array}{l}\text { Coxiella } \\
\text { burnetii }\end{array}$ & \\
\hline 1 & $0.45 \pm 0.04$ & $0.39 \pm 0.04$ & $0.45 \pm 0.04$ & $0.43 \pm 0.047$ \\
\hline 7 & $\begin{array}{l}0.34 \pm 0.04 \\
(\downarrow 17 \%)^{*}\end{array}$ & $\begin{array}{l}0.43 \pm 0.07 \\
(\uparrow 5 \%)^{*}\end{array}$ & $\begin{array}{l}0.35 \pm 0.03 \\
(\downarrow 15 \%)^{*}\end{array}$ & $0.41 \pm 0.04$ \\
\hline 14 & $\begin{array}{l}0.36 \pm 0.06^{*} \\
(\downarrow 18 \%)\end{array}$ & $\begin{array}{l}0.44 \pm 0.03 \\
(\uparrow 2 \%)^{*}\end{array}$ & $\begin{array}{l}0.31 \pm 0.03 \\
(\downarrow 28 \%)^{*}\end{array}$ & $0.43 \pm 0.04$ \\
\hline 21 & $\begin{array}{l}0.48 \pm 0.04 \\
(\uparrow 4 \%)^{*}\end{array}$ & $\begin{array}{l}0.55 \pm 0.04 \\
(\uparrow 20 \%)^{*}\end{array}$ & $\begin{array}{l}0.34 \pm 0.02 \\
(\downarrow 26 \%)^{*}\end{array}$ & $0.46 \pm 0.04$ \\
\hline 28 & $\begin{array}{c}0.49 \pm 0.03 \\
(\uparrow 2 \%)^{*}\end{array}$ & $\begin{array}{c}0.56 \pm 0.04 \\
(\uparrow 17 \%)^{*}\end{array}$ & $\begin{array}{l}0.35 \pm 0.03 \\
(\downarrow 27 \%)^{*}\end{array}$ & $0.48 \pm 0.04$ \\
\hline
\end{tabular}

* percentage of increase $(\uparrow)$ or decrease $(\downarrow)$ of caspase 3 activity levels calculated as a ratio of the levels in infected to uninfected HEL299 cells 


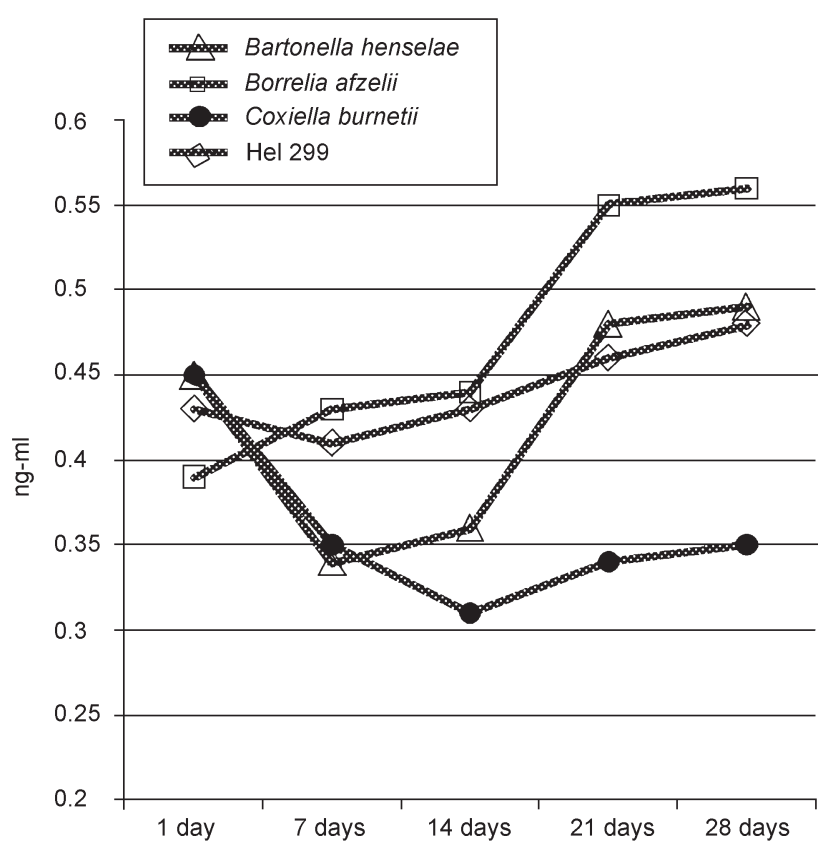

Fig. 1. Caspase 3 activity in uninfected HEL-299 cells and in cells infected with $B$. henselae, B. afzelii and C. burnetii

They have been observed in the fibroblasts and after 48 hours they are released to the extracellular space. This indicates that they stay in a cell only a short time (Chmielewski and Tylewska-Wierzbanowska, 2010). Thus, their ability to inhibit apoptosis is limited.

Bacteria of the genus Bartonella, in the human body attach to epithelial cells and in the process of phagocytosis, they penetrate into the cells and multiply inside. They have an ability to form large aggregates. This structure creates perfect conditions for bacterial replication, protecting them from the host immune defense and degrading enzymes, present in lysosomes. Next, these organisms are released into the cytoplasm, in which produce and secrete factors stimulatinge cell proliferation, activation of pro-inflammatory factors and inhibiting apoptosis. After 4 days of infection, bacteria are released to the blood stream and penetrate into the erythrocytes and multiply intracellularly (Guz and Goroszkiewicz, 2009; Kordick et al., 1999). Ability to inhibit apoptosis in fibroblast culture in vitro, was observed especially between 7 to 14 days of infection.

C. burnetii after successfully evading host defense mechanisms is able to inhibit apoptosis to survive and to multiply inside the cells. Inhibition of apoptosis has been observed among intracellular pathogens with characteristic slow multiplication to establish a productive infection. (Carmen et al., 2006; Clifton et al., 1998; Fischer et al., 2004). C. burnetii infection affects the expression of multiple apoptosis-related genes and resulting in increased synthesis of the antiapoptotic proteins such as A1/Bfl-1 and c-IAP2, prosurvival kinases Akt and Erk1/2 (extracellular signal-regulated kinases 1 and 2). C. burnetii infection of THP-1 human macrophage-like cells caused increased levels of phosphorylated c-Jun, Hsp27, Jun N-terminal protein kinase, and p38 protein. This pathogen can interfere with the intrinsic cell death pathway during infection by producing proteins that either directly or indirectly prevent release of cytochrome $c$ from mitochondria. To summarize, these results indicate the importance of C. burnetii modulation of host signaling in successful intracellular parasitism and maintenance of host cell viability (Voth et al., 2007; Voth and Heinzen, 2009; Lührmann and Roy 2007).

C. burnetii is the one of the obligate intracellular pathogens that can infect mammalian monocytes and macrophages in vivo and can grow in Vero, fibroblast and macrophagelike cells in vitro. Our findings show that C. burnetii bacteria may inhibit the process of apoptosis in the host cells for a long time. It can be the crucial pathogenic mechanism which permits the pathogen to survive intracellularly in the host and to mediate the development of chronic disease.

C. burnetii has to inhibit host cell death to provide a stable, intracellular niche for the course of the pathogen's infectious cycle. In cultures C. burnetii-infected cells can be maintained for weeks.

\section{Literature}

Carmen J.C., L. Hardi and A.P. Sinai. 2006. Toxoplasma gondii inhibits ultraviolet light-induced apoptosis through multiple interactions with the mitochondrion-dependent programmed cell death pathway. Cell Microbiol. 8: 301-315.

Chmielewski T. and S. Tylewska-Wierzbanowska. 2010. Interactions between Borrelia burgdorferi and mouse fibroblasts. Pol. J. Microbiol. 59: 157-160.

Clifton D.R., R.A. Goss, S.K. Sahni, D. van Antwerp, R.B. Baggs, V.J. Marder, D.J. Silverman and L.A. Sporn. 1998. NF-kappa B-dependent inhibition of apoptosis is essential for host cell survival during Rickettsia rickettsii infection. Proc. Natl. Acad. Sci. USA 95: 4646-4651.

Dörbecker C., A. Sander, K. Oberle and T. Schülin-Casonato. 2006 In vitro susceptibility of Bartonella species to 17 antimicrobial compounds: comparison of Etest and agar dilution. J. Antimicrob. Chemother. 58: 784-788.

Fischer S.F., J. Vier, S. Kirschnek, A. Klos, S. Hess, S. Ying and G. Häcker. 2004. Chlamydia inhibit host cell apoptosis by degradation of proapoptotic BH3-only proteins. J. Exp. Med. 200: 905-916. Gołąb J. 2009. Immunologia. (in Polish) Wydawnictwo Naukowe PWN, Warszawa

Guz K. and W. Goroszkiewicz. 2009. Biology ecology and pathogenesis of Bartonella sp. (in Polish). Post. Mikrobiol. 48, 43-54.

Hu L.T. and M.S. Klempner. 1997. Host-pathogen interactions in the immunopathogenesis of Lyme disease. J. Clin. Immunol. 17: 354-365.

Klempner M.S., R. Noring and R.A. Rogers. 1993. Invasion of human skin fibroblasts by the Lyme disease spirochete, Borrelia burgdorferi. J. Infect. Dis. 167: 1074-1081.

Kordick D.L., T.T. Brown, K. Shin and E.B. Breitschwerdt. 1999. Clinical and pathologic evaluation of chronic Bartonella henselae or Bartonella clarridgeiae infection in cats. J. Clin. Microbiol. 37: 1536-1547. 
Linder S., C. Heimerl, V. Fingerle, M. Aepfelbacher and B. Wilske. 2001. Coiling phagocytosis of Borrelia burgdorferi by primary human macrophages is controlled by CDC42Hs and Rac 1 and involves recruitment of Wiskott-Aldrich syndrome protein and Arp2/3 complex. Infect. Immun. 69: 1739-46.

Lührmann A. and C.R. Roy. 2007. Coxiella burnetii inhibits activation of host cell apoptosis through a mechanism that involves preventing cytochrome $\mathrm{c}$ release from mitochondria. Infect. Immun. 75: 5282-5289.

Peters J.D. and J.L. Benach. 1997. Borrelia burgdorferi adherence and injury to undifferentiated and differentiated neural cells in vitro. J. Infect. Dis. 176: 470-477.

Pollack R.J., S.R. Teleford III and A. Spielman. 1993. Standardization of medium for culturing Lyme disease spirochetes. J. Clin. Microbiol. 31: 1251-1255.

Radulovic S., Price P.W., Beier M.S., Gaywee J., Macaluso J.A., and Azad A. 2002. Rickettsia-macrophage interactions: host cell responses to Rickettsia akari and Rickettsia typhi. Infect. Immun. 70: 2576-2582.
Raoult D., G. Vestris and M. Enea. 1990. Isolation of 16 strains of Coxiella burnetii from patients by using a sensitive centrifugation cell culture system and establishment of the strains in HEL cells. J. Clin. Microbiol. 28(11): 2482-2484.

Sigal L.H. 1997. Lyme disease: a review of aspects of its immunology and immunopathogenesis. Ann. Rev. Immunol. 15: 63-92.

Szczepanski A., M.B. Furie, J.L. Benach, B.P. Lane and B. Fleit. 1990. Interaction between Borrelia burgdorferi and endothelium in vitro. J. Clin. Invest. 85: 1637-1647.

Thomas D.D. and L.E. Comstock. 1989. Interaction of Lyme disease spirochetes with cultured eucaryotic cells. Infect. Immun. 57: 1324-1326.

Voth D.E. and R.A. Heinzen. 2009. Sustained activation of Akt and Erk1/2 is required for Coxiella burnetii antiapoptotic activity. Infect. Immun. 77: 205-213.

Voth D.E., D. Howe and R.A. Heinzen. 2007. Coxiella burnetii inhibits apoptosis in human THP-1 cells and monkey primary alveolar macrophages. Infect. Immun. 75: 4263-4271. 